\title{
Optimal Pre-Treatment Processes for Microwavable Puffed Job's Tears Grains
}

\author{
Somchai Jomduang* and Orathai Bunthawong \\ Division of Food Science and Technology, Faculty of Agro-Industry, Chiang Mai University, \\ Chiang Mai 50100, Thailand \\ *Corresponding author.E-mail: somchai.j@cmu.ac.th \\ https://doi.org/10.12982/CMUJNS.2019.0009
}

Received: July 16, 2018

Revised: October 1, 2018

Accepted: October 9, 2018

\begin{abstract}
Job's tears (Coix lachryma-jobi L.) grains after puffing, had potential to be used as raw material for snack foods. Puffing job's grains using microwave oven could provide low fat content raw material. This research focused on the pre-treatment processes that affected the expansion and other qualities of Job's tears that were puffed in a microwave oven. Four forms of Job's tears grains were used as raw materials in this research: unpolished black Job's tears (UBJ), polished black Job's tears (PBJ), unpolished white Job's tears (UWJ), and polished white Job's tears (PWJ). The pre-treatment processes consisted of soaking, cooking, and drying, before puffing in a microwave oven. Each process was studied for the optimal conditions. By soaking Job's tears grains in water for 24 hours at room temperature, it was found that the suitable soaking time was 10 hours. This was the minimal soaking time that facilitated constant water uptake. Cooking using the autoclave at 15 psi for 20 minutes was suitable for achieving a good expansion ratio for the microwavable puffed grains. Cooking with this method followed by drying and puffing resulted in the maximal expansion ratio for the puffed product. Drying in the tray dryer at $60^{\circ} \mathrm{C}$ for about 5.5-6.0 hours until the $8.00-10.60 \%$ moisture content was achieved was suitable for pre-treated Job's tears grains. Puffing in a microwave oven at this moisture content level produced puffed Job's tears grains with a high expansion ratio. Based on this study, optimal pretreatment could be applied to all the forms of studied Job's tears.
\end{abstract}

Keywords: Job's tears grains, Puffed Job's tears, Microwave oven, Expansion ratio, Pre-treatment process 


\section{INTRODUCTION}

Currently marketed snack foods or mini-meals consist primarily of starch and fat, which are of little nutritional value. The excessive intake of such snacks will make one feel full, leading to less consumption of wholesome meals. This, in turn, can result in nutrient imbalance and malnutrition. Thus, consumers are seeking healthier choices. The consumption of whole or unpolished cereal grains has becomes popular among health enthusiasts. They get maximum benefits from the grains, which are not processed through attrition or seed coat removal. Generally, the final nutrient content is lower in grains that are polished. For instance, polished rice has lost most of the germ and bran, which contain nutrients and minerals. The remaining white rice grain has fewer nutrients (protein, fat, crude fiber, ash, dietary fiber, and energy) (Naivikul, 2004).

Grains can be processed into various products and consumed as main courses and mini-meals. One interesting grain is Job's tears (Coix lachryma-jobi L.), a cereal that can potentially be transformed into snacks. The nutritious grain has protein, riboflavin, niacin, calcium, phosphorus, potassium, iron, and total dietary fiber content. Not only can Job's tears be transformed into a health supplement, but they can also be classified as nutraceutical because of their properties in treatment. A pharmacological study found that when coixenolide [1-methyl-2-(cis-9-hexadecenoyloxy) propyl trans-11-octadecenoate, $\mathrm{C}_{38} \mathrm{H}_{70} \mathrm{O}_{4}$ ], an extract of Job's tears, was isolated from the grains, it exhibited antitumour activity towards ascites sarcoma in mice (Tanimura, 1961; Ukita and Tanimura, 1961) as cited by Yang et al. (2004).

Previous work found that Job's tears grains could be transformed into cereal drinks, quick-cooked Job's tears grains, and various flavours of fried, crispy Job's tears grains. However, the production of the fried crispy version is closely associated with cooking with oil. In addition, it becomes rancid quickly, resulting in a short shelf life. Modifying the production process for Job's tears grains from the preparation of fried snacks to that of puffed snacks results in fat content reduction, shelf-life extension, and the reduction of some operating costs. Microwave puffing is one puffing technique that fits in with the modern consumer's lifestyle and can also be applied to commercial production. Pre-treatment for the Job's tears raw material should involve optimal conditions. Therefore, the goal of this research is to develop a manufacturing process for puffed Job's tears grains using a microwave technique. Pre-treatment processes included soaking, cooking, and drying, before microwave puffing.

\section{MATERIALS AND METHODS}

\section{Materials}

Two varieties of Job's tears grains were used as raw materials; black husk and white husk.

The black husk Job's tears grains were two forms of purchased grain; unpolished black Job's tears (UBJ) and polished black Job's tears (PBJ). All raw materials were packed in tightly sealed plastic bags and stored in cold room $\left(4 \pm 1^{\circ} \mathrm{C}\right)$ for future studying.

The white husk Job's tears grains were sent to CCP Northern Co., Ltd. for grain milling. After milling, there were two forms; unpolished white Job's tears (UWJ) and polished white Job's tears (PWJ). They were packed and stored in the same condition of the previous raw materials. 


\section{Study on chemical composition analysis of Job's tears grains}

The dry milling method was used to grind each of the four forms of Job's tears grains (UBJ, PBJ, UWJ, and PWJ) into flour with the help of the dry milling machine (Basic Analytical mill model A11, IKA Germany). After grinding, the flour was sifted using a 0.25mm. sieve (Mesh No. 60) and then kept in tight containers.

The chemical composition of each of the four Job's tears flour samples was determined as follows:

- Proximate analysis: moisture, fat, protein, crude fiber, ash, total dietary fiber, and carbohydrate contents by AOAC (2005).

- Amylose content was determined by Juliano (1971).

- Retinol was determined by HPLC (AOAC, 2005).

- Thiamin, riboflavin, and niacin were determined by HPLC (Finglasa and Faulksa, 1994).

- Calcium, iron, phosphorus, and potassium were determined by AOAC (2005).

- Gamma-amino butyric acid (GABA) content was determined by HPLC according to Jannoey et al. (2010).

- Coixenolide content was determined by Gas Chromatography (GC) according to Yang et al. (2004) and Chaisiricharoenkul et al. (2011).

The experimental design was a completely randomized design (CRD) with 3 replications. The data obtained from the experiments were processed with the Analysis of Variance (ANOVA) and mean compared using Duncan's new multiple range test $(P \leq 0.05)$.

\section{Study on effect of soaking time on the water uptake of Job's tears grains}

Each form of Job's tears grains (UBJ, PBJ, UWJ, and PWJ) was washed and cleaned then soaked in water at room temperature using the ratio of Job's tears grains to water of 1:2. After soaking, soaked grains were randomly taken every 2 hours during the 24 hour soaking. Data for moisture content (AOAC, 2005), water uptake (Neher et al., 2014), and solid loss were measured from each period.

The experimental design for each form of Job's tears grains entailed a completely randomized design (CRD) with 3 replications. The data obtained from the experiments were processed with the Analysis of Variance (ANOVA) and mean compared using Duncan's new multiple range test $(P \leq 0.05)$. The optimal soaking time was the minimal soaking time that facilitated constant water uptake.

\section{Study on effect of cooking conditions on expansion ratio of puffed Job's tears grains}

Each form of Job's tears grains (UBJ, PBJ, UWJ, and PWJ) was soaked and then cooked using three cooking methods (14 cooking conditions) under different conditions as follows:

- Cooking by kitchen steamer for 40, 50, 60, and 70 minutes.

- Cooking by autoclave at a constant pressure of 10 psi for 10, 15, 20, and 25 minutes.

- Cooking by autoclave at a constant pressure of 15 psi for 5, 10, 15, 20, 30, and 40 minutes. 
After cooking with each method, the moisture content of the Job's tears was analyzed (AOAC, 2005). Job's tears grains cooked under each set of conditions were dried at $65^{\circ} \mathrm{C}$ for 3 hours or until the moisture about $12 \pm 1 \%$ (modified method of Bunthawong et al., 2012). After drying, they were packed into tightly sealed aluminum foil bag and stored overnight at room temperature to balance the moisture content (Jomduang, 1994). After overnight moisture equilibrium, pre-treated Job's tears grains were obtained. The moisture content of them was measured (AOAC, 2005). All of them from 14 cooking conditions were puffed in a microwave oven (Capacity $20 \mathrm{~L}, \mathrm{ME} 712 \mathrm{~N}$ model, Samsung, Malaysia) at maximum power ( $800 \mathrm{~W}$ ) for 2 minutes or until they were completely expanded (modified method of Bunthawong et al., 2012). Afterwards, the puffed Job's tears grains were subjected to expansion ratio analyzed. The expansion ratios were measured using the sesame seed displacement method according to Nath and Chattopadhyay (2008).

The experimental design for each form of Job's tears entailed a completely randomized design (CRD) with 3 replications. The data obtained from the experiments were processed with the Analysis of Variance (ANOVA) and mean compared using Duncan's new multiple range test $(P \leq 0.05)$. The optimal cooking condition which could provide the maximum expansion ratio was selected.

\section{Study on effect of moisture content of pre-treated Job's tears grains on expansion ratio of puffed Job's tears grains}

Each form of Job's tears grains (UBJ, PBJ, UWJ, and PWJ) was soaked in water, cooked, and dried by tray dryer at $60^{\circ} \mathrm{C}$ for 6 hours. Random samples were taken every 30 minutes. After drying and cooling, they were packed into a tightly sealed aluminium foil bag in order to balance the moisture content (Jomduang, 1994). The moisture content of the dried Job's tears grains was then measured (AOAC, 2005).

Pre-treated Job's tears grains for each drying time were microwave puffed at maximum power ( 800 watts) for 2 minutes or until they were completely expanded (modified method of Bunthawong et al., 2012). The examination of the quality of the puffed Job's tears grains involved measuring the expansion ratio (Nath and Chattopadhyay, 2008). The optimum moisture content that could provide the maximum expansion ratio was selected.

The experimental design for each form of Job's tears grains entailed a completely randomized design (CRD) with 3 replications. The data obtained from the experiments were processed with the Analysis of Variance (ANOVA) and mean compared using Duncan's new multiple range test $(P \leq 0.05)$.

\section{RESULTS}

\section{Chemical compositions of Job's tears grains}

The black and white husk Job's tears grains were similar in size. The husk colour of the black husk Job's tears grains ranged from dark brown to black, and the husk colour of the white husk Job's tears grains ranged from light brown to grey-brown (Figure 1). After preparation, the unpolished black and white Job's tears grains were similar in body size and were hemispherical in shape with brown skin (of which one side was relatively smooth and the 
other side was curved with a groove). There were four forms of Job's tears grains that would be studied; unpolished black Job's tears (UBJ), polished black Job's tears (PBJ), unpolished white Job's tears (UWJ), and polished white Job's tears (PWJ).
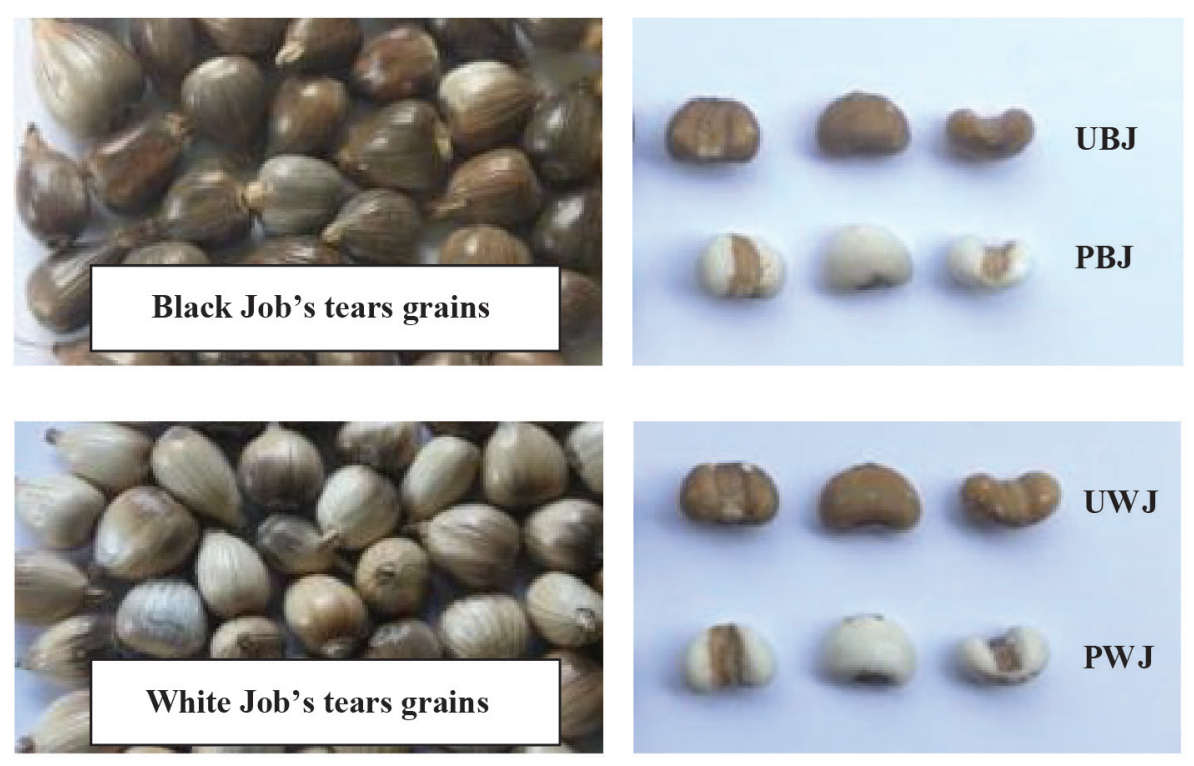

Figure 1. Appearance characteristics of black and white husk Job's tears grains (UBJ = Unpolished Black Job's tears, PBJ = Polished Black Job's tears, UWJ = Unpolished White Job's tears, PWJ = Polished White Job's tears).

When the basic chemical composition of each of the four forms of Job's tears grains was analyzed, the results showed that black Job's tears grains had higher amounts of protein, fat, and ash than white ones. Black Job's tears grains contained 14.22-14.29\% protein, 5.70$6.44 \%$ fat, and $2.12-2.29 \%$ ash, whereas white Job's tears grains contained $12.90 \%$ protein, $4.20-6.11 \%$ fat, and $0.33-0.69 \%$ ash (Table 1). According to other chemical composition analyses, 3.86-4.26\% amylose was found in black Job's tears grains. That was higher than the $3.32-3.92 \%$ amylose in white Job's tears grains (Table 2). The analysis of total dietary fiber (TDF) showed that the four forms of Job's tears grains had TDF in the range of 3.23-10.51\%. The other chemical composition analyses of the four forms of Job's tears grains revealed that none of them had retinol and PWJ had no retinol. The Job's tears grains had 0.01-0.38 mg/100 g of thiamin, $0.03-0.06 \mathrm{mg} / 100 \mathrm{~g}$ of riboflavin, $1.80-3.94 \mathrm{mg} / 100 \mathrm{~g}$ of niacin, $12.23-15.80 \mathrm{mg} /$ $100 \mathrm{~g}$ of calcium, 2.66-3.78 mg/100 $\mathrm{g}$ of iron, $106.1-474.20 \mathrm{mg} / 100 \mathrm{~g}$ of phosphorus, and $108.60-343.10 \mathrm{mg} / 100 \mathrm{~g}$ of potassium. The four forms of Job's tears grains had $0.37-1.77 \mathrm{mg} /$ $100 \mathrm{~g}$ of GABA. They also had 7.05-9.05 mg/100 g (70.5-90.50 $\mu \mathrm{g} / \mathrm{g})$ of coixenolide. It was also found that Job's tears grains had 364.32-371.71 Kcal/100 $\mathrm{g}$ of food calories. 
Table 1. Chemical composition of each form of Job's tears grains.

\begin{tabular}{lcccc}
\hline Proximate analysis & UBJ & PBJ & UWJ & PWJ \\
\hline Moisture $^{\mathrm{ns}}(\%)$ & $12.50 \pm 0.08$ & $13.24 \pm 0.84$ & $13.37 \pm 0.56$ & $13.44 \pm 0.03$ \\
Protein $(\% \mathrm{db})$ & $14.22^{\mathrm{a}} \pm 0.04$ & $14.29^{\mathrm{a}} \pm 0.06$ & $12.90^{\mathrm{b}} \pm 0.10$ & $12.90^{\mathrm{b}} \pm 0.11$ \\
Fat $(\% \mathrm{db})$ & $6.11^{\mathrm{b}} \pm 0.04$ & $5.70^{\mathrm{c}} \pm 0.02$ & $6.44^{\mathrm{a}} \pm 0.03$ & $4.20^{\mathrm{d}} \pm 0.05$ \\
Ash $(\% \mathrm{db})$ & $2.29^{\mathrm{a}} \pm 0.03$ & $2.12^{\mathrm{b}} \pm 0.01$ & $0.69^{\mathrm{c}} \pm 0.13$ & $0.33^{\mathrm{d}} \pm 0.03$ \\
Carbohydrate $(\% \mathrm{db})$ & $64.88^{\mathrm{b}} \pm 0.21$ & $64.70^{\mathrm{b}} \pm 2.01$ & $66.59^{\mathrm{b}} \pm 0.66$ & $69.17^{\mathrm{a}} \pm 0.16$ \\
\hline
\end{tabular}

Note: Different superscripts in the same row indicate statistically significant values $(P \leq 0.05)$; ${ }^{\text {ns }}=$ mean values in the same row are not significantly different $(P>0.05)$; UBJ $=$ unpolished black Job's tears; $\mathrm{PBJ}=$ polished black Job's tears; UWJ = unpolished white Job's tears; PWJ = polished white Job's tears.

Table 2. Other chemical compositions and calories associated with each form of Job's tears grains.

\begin{tabular}{lcccc}
\hline \multirow{2}{*}{ Chemical compositions } & \multicolumn{4}{c}{ Quantity } \\
\cline { 2 - 5 } & UBJ & PBJ & UWJ & PWJ \\
\hline Amylose (\%) & $3.86^{\mathrm{a}} \pm 0.19$ & $4.26^{\mathrm{a}} \pm 0.10$ & $3.32^{\mathrm{b}} \pm 0.20$ & $3.92^{\mathrm{a}} \pm 0.36$ \\
Total dietary fiber (\%) & $10.51^{\mathrm{a}} \pm 0.90$ & $9.41^{\mathrm{a}} \pm 0.66$ & $5.72^{\mathrm{b}} \pm 0.07$ & $3.23^{\mathrm{c}} \pm 0.11$ \\
Retinol $(\mu \mathrm{g} / 100 \mathrm{~g})$ & Not Detected & Not Detected & Not Detected & Not Detected \\
Thiamin $(\mathrm{mg} / 100 \mathrm{~g})$ & $0.38^{\mathrm{a}} \pm 0.00$ & $0.31^{\mathrm{b}} \pm 0.00$ & $0.01^{\mathrm{c}} \pm 0.00$ & $0.00^{\mathrm{d}} \pm 0.00$ \\
Riboflavin $(\mathrm{mg} / 100 \mathrm{~g})$ & $0.06^{\mathrm{a}} \pm 0.00$ & $0.04^{\mathrm{c}} \pm 0.00$ & $0.05^{\mathrm{b}} \pm 0.00$ & $0.03^{\mathrm{d}} \pm 0.00$ \\
Niacin $(\mathrm{mg} / 100 \mathrm{~g})$ & $3.94^{\mathrm{a}} \pm 0.14$ & $1.80^{\mathrm{c}} \pm 0.06$ & $3.85^{\mathrm{a}} \pm 0.13$ & $2.19^{\mathrm{b}} \pm 0.06$ \\
Calcium $(\mathrm{mg} / 100 \mathrm{~g})$ & $13.70^{\mathrm{a}} \pm 0.25$ & $12.23^{\mathrm{b}} \pm 0.28$ & $14.94^{\mathrm{a}} \pm 0.96$ & $15.80^{\mathrm{a}} \pm 1.22$ \\
Iron $(\mathrm{mg} / 100 \mathrm{~g})$ & $3.42^{\mathrm{a}} \pm 0.11$ & $3.33^{\mathrm{a}} \pm 0.32$ & $3.78^{\mathrm{a}} \pm 0.26$ & $2.66^{\mathrm{b}} \pm 0.14$ \\
Phosphorus $(\mathrm{mg} / 100 \mathrm{~g})$ & $502.40^{\mathrm{a}} \pm 12.87$ & $455.60^{\mathrm{ab}} \pm 28.14$ & $421.70^{\mathrm{b}} \pm 15.42$ & $106.10^{\mathrm{c}} \pm 8.20$ \\
Potassium $(\mathrm{mg} / 100 \mathrm{~g})$ & $256.40^{\mathrm{b}} \pm 13.86$ & $226.90^{\mathrm{b}} \pm 11.60$ & $343.10^{\mathrm{a}} \pm 14.85$ & $108.60^{\mathrm{c}} \pm 1.98$ \\
GABA (mg/100 g) & $0.75^{\mathrm{b}} \pm 0.24$ & $0.37^{\mathrm{c}} \pm 0.09$ & $1.77^{\mathrm{a}} \pm 0.14$ & $0.62^{\mathrm{b}} \pm 0.06$ \\
Coixenolide $(\mathrm{mg} / 100 \mathrm{~g})$ & $8.35^{\mathrm{b}} \pm 0.42$ & $7.05^{\mathrm{c}} \pm 0.12$ & $9.05^{\mathrm{a}} \pm 0.12$ & $8.14^{\mathrm{b}} \pm 0.23$ \\
\hline Energy $(\mathrm{Kcal} / 100 \mathrm{~g})$ & $371.40^{\mathrm{ab}} \pm 0.89$ & $366.81^{\mathrm{b}} \pm 6.37$ & $375.94^{\mathrm{a}} \pm 3.06$ & $365.67^{\mathrm{b}} \pm 0.82$ \\
\hline
\end{tabular}

Note: Different superscripts in the same row indicate statistically significant values $(P \leq 0.05)$; ${ }^{\text {ns }}$ mean values in the same row are not significantly different $(P>0.05)$; UBJ $=$ Unpolished Black Job's tears; PBJ = Polished Black Job's tears; UWJ = Unpolished White Job's tears; PWJ = Polished White Job's tears.

\section{Effect of soaking time on water uptake of Job's tears grains}

When four forms of Job's tears grains were soaked in water at room temperature for 24 hours and randomly picked as samples every 2 hours, it was found that they had statistically significant differences in the amounts of absorption $(P \leq 0.05)$ during the first 1-6 hours (Table 3), and the moisture content had rapidly increased (Figure 2). The water absorption and the moisture did not change significantly in the soaking period of 8-10 hours and remained relatively constant for 10-24 hours of soaking, which was not significantly different $(P>0.05)$. 
Table 3. Water uptake and solid loss for different soaking times for each type of Job's tears grains.

\begin{tabular}{|c|c|c|c|c|c|c|c|c|}
\hline \multirow{2}{*}{$\begin{array}{l}\text { Time } \\
\text { (h) }\end{array}$} & \multicolumn{4}{|c|}{ Water uptake (\%) } & \multicolumn{4}{|c|}{ Solid loss (\%) } \\
\hline & UBJ & PBJ & UWJ & $\mathbf{P W} \mathbf{J}^{\mathrm{ns}}$ & $\mathbf{U B} \mathbf{J}^{\mathrm{ns}}$ & PBJ $J^{\mathrm{ns}}$ & $\mathbf{U W J}^{\mathrm{ns}}$ & PWJ \\
\hline 2 & $27.73^{\mathrm{d}} \pm 1.66$ & $30.12^{\mathrm{d}} \pm 0.13$ & $35.64^{\mathrm{d}} \pm 0.06$ & $37.43 \pm 0.20$ & $7.13 \pm 0.22$ & $2.22 \pm 0.49$ & $7.18 \pm 0.74$ & $1.03^{\mathrm{c}} \pm 0.08$ \\
\hline 4 & $35.44^{c} \pm 1.14$ & $35.62^{\mathrm{c}} \pm 0.29$ & $41.12^{c} \pm 0.04$ & $37.90 \pm 0.38$ & $7.76 \pm 0.07$ & $2.35 \pm 0.35$ & $7.32 \pm 0.21$ & $1.66^{\mathrm{bc}} \pm 0.30$ \\
\hline 6 & $37.99^{\mathrm{c}} \pm 2.29$ & $37.09^{\mathrm{bc}} \pm 0.81$ & $41.89^{\mathrm{bc}} \pm 0.04$ & $38.68 \pm 1.58$ & $7.48 \pm 0.26$ & $2.66 \pm 0.52$ & $7.88 \pm 0.62$ & $2.72^{\mathrm{a}} \pm 0.33$ \\
\hline 8 & $41.60^{b} \pm 1.77$ & $37.80^{\mathrm{ab}} \pm 0.53$ & $42.76^{\mathrm{ab}} \pm 0.92$ & $39.77 \pm 0.63$ & $6.73 \pm 0.22$ & $2.89 \pm 0.20$ & $6.26 \pm 0.65$ & $2.82^{\mathrm{a}} \pm 0.09$ \\
\hline 10 & $44.23^{\mathrm{ab}} \pm 0.15$ & $37.85^{\mathrm{ab}} \pm 0.77$ & $42.61^{\mathrm{ab}} \pm 0.54$ & $39.71 \pm 1.58$ & $6.77 \pm 0.24$ & $3.13 \pm 0.69$ & $6.08 \pm 0.28$ & $2.55^{\mathrm{ab}} \pm 0.78$ \\
\hline 12 & $44.82^{\mathrm{ab}} \pm 1.82$ & $38.16^{\mathrm{ab}} \pm 0.89$ & $43.11^{\mathrm{a}} \pm 0.52$ & $40.09 \pm 2.05$ & $6.84 \pm 0.37$ & $3.52 \pm 0.12$ & $7.15 \pm 0.14$ & $2.69^{\mathrm{a}} \pm 0.35$ \\
\hline 14 & $45.14^{\mathrm{ab}} \pm 2.35$ & $38.33^{\mathrm{ab}} \pm 1.31$ & $42.62^{\mathrm{ab}} \pm 0.43$ & $41.86 \pm 1.05$ & $7.51 \pm 0.13$ & $3.60 \pm 0.08$ & $7.28 \pm 0.73$ & $2.45^{\mathrm{ab}} \pm 0.16$ \\
\hline 16 & $46.20^{\mathrm{a}} \pm 1.06$ & $38.30^{\mathrm{ab}} \pm 1.29$ & - & - & $7.20 \pm 0.47$ & $3.41 \pm 0.67$ & - & - \\
\hline 18 & $46.89^{\mathrm{a}} \pm 1.39$ & $39.26^{\mathrm{a}} \pm 0.37$ & - & - & $6.91 \pm 0.38$ & $3.22 \pm 0.52$ & - & - \\
\hline 20 & $46.67^{\mathrm{a}} \pm 1.09$ & $39.27^{\mathrm{a}} \pm 0.42$ & - & - & $7.01 \pm 0.36$ & $2.88 \pm 0.40$ & - & - \\
\hline 22 & $46.58^{\mathrm{a}} \pm 1.52$ & $38.82^{\mathrm{ab}} \pm 0.73$ & - & - & $7.02 \pm 0.21$ & $3.21 \pm 0.42$ & - & - \\
\hline
\end{tabular}

Note: Different superscripts in the same row indicate statistically significant values $(P \leq 0.05)$; ${ }^{\text {ns }}$ mean values in the same row are not significantly different $(P>0.05)$. UBJ $=$ Unpolished Black Job's tears; PBJ = Polished Black Job's tears; UWJ = Unpolished White Job's tears; PWJ = Polished White Job's tears.

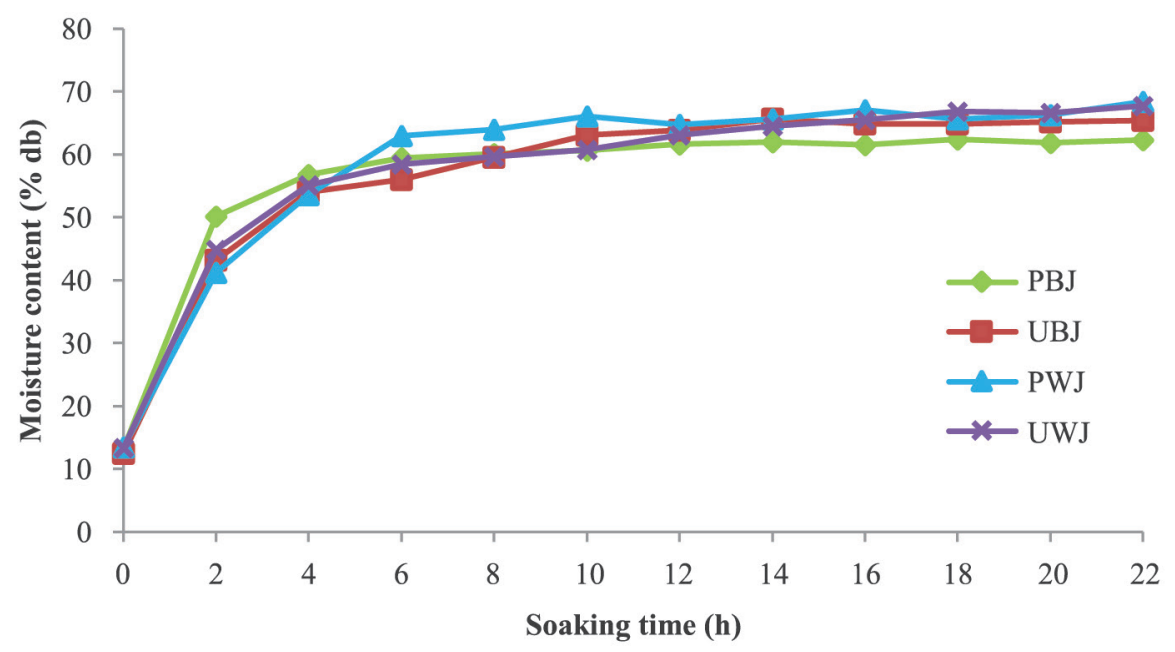

Figure 2. Moisture content for different soaking times for each type of Job's tears grain (UBJ = Unpolished Black Job's tears; PBJ = Polished Black Job's tears; UWJ = Unpolished White Job's tears; PWJ = Polished White Job's tears). 


\section{Effect of cooking conditions on expansion ratio of puffed Job's tears grains}

The study on cooking conditions for Job's tears grains was implemented by soaking the four forms of Job's tears grains at room temperature for 10 hours then applying heat to them until they were cooked in different ways and at different times. The results suggested that the methods and heating periods affected the expansion ratio of the four forms with statistical difference $(P \leq 0.05)$ (Table 4$)$. Steaming in an autoclave at 15 psi for 20 minutes, which was the maximum pressure and the longest period of time, provided the highest expansion ratio for the four forms of Job's tears grains, demonstrating that such an approach was an appropriate method for cooking Job's tears grains and rendering them best swollen.

Table 4. The expansion ratio of each form of Job's tears grains cooked by different methods.

\begin{tabular}{|c|c|c|c|c|c|}
\hline \multirow{2}{*}{ Cooking method } & \multirow{2}{*}{$\begin{array}{l}\text { Cooking time } \\
\text { (min) }\end{array}$} & \multicolumn{4}{|c|}{ Expansion ratio } \\
\hline & & UBJ & PBJ & UWJ & PWJ \\
\hline \multirow[t]{4}{*}{ Kitchen steamer } & 40 & $1.36^{\mathrm{cd}} \pm 0.09$ & $1.19^{\mathrm{g}} \pm 0.01$ & $1.29^{\mathrm{f}} \pm 0.01$ & $1.32^{\operatorname{cdef}} \pm 0.22$ \\
\hline & 50 & $1.28^{\mathrm{de}} \pm 0.03$ & $1.40^{\text {cdef }_{ \pm}} \pm 0.01$ & $1.29^{\mathrm{f}} \pm 0.06$ & $1.23^{\mathrm{fg}} \pm 0.03$ \\
\hline & 60 & $1.20^{\mathrm{e}} \pm 0.02$ & $1.35^{\mathrm{ef}} \pm 0.13$ & $1.30^{\mathrm{f}} \pm 0.20$ & $1.25^{\mathrm{fg}} \pm 0.04$ \\
\hline & 70 & $1.27^{\mathrm{de}} \pm 0.17$ & $1.39^{\mathrm{def}} \pm 0.07$ & $1.38^{\mathrm{def}} \pm 0.04$ & $1.16^{\mathrm{g}} \pm 0.01$ \\
\hline \multirow[t]{4}{*}{ Autoclave, 10 psi } & 10 & $1.29^{\mathrm{de}} \pm 0.08$ & $1.38^{\mathrm{bef}} \pm 0.10$ & $1.41^{\mathrm{def}} \pm 0.06$ & $1.31^{\operatorname{cdef}} \pm 0.06$ \\
\hline & 15 & $1.58^{\mathrm{b}} \pm 0.06$ & $1.45^{\mathrm{bcde}} \pm 0.05$ & $1.44^{\text {cdef }} \pm 0.07$ & $1.42^{\mathrm{bcde}} \pm 0.04$ \\
\hline & 20 & $1.49^{b c} \pm 0.01$ & $1.55^{\mathrm{bc}} \pm 0.03$ & $1.46^{\mathrm{cde}} \pm 0.04$ & $1.47^{\mathrm{bc}} \pm 0.03$ \\
\hline & 25 & $1.53^{\mathrm{b}} \pm 0.03$ & $1.56^{\mathrm{b}} \pm 0.07$ & $1.62^{\mathrm{ab}} \pm 0.10$ & $1.51^{\mathrm{b}} \pm 0.06$ \\
\hline \multirow[t]{6}{*}{ Autoclave, 15 psi } & 5 & $1.36^{\mathrm{cd}} \pm 0.04$ & $1.30^{\mathrm{efg}} \pm 0.02$ & $1.40^{\mathrm{def}_{ \pm}} \pm 0.01$ & $1.33^{\text {bcdef }} \pm 0.01$ \\
\hline & 10 & $1.50^{\mathrm{bc}} \pm 0.03$ & $1.28^{\mathrm{fg}} \pm 0.06$ & $1.49^{\mathrm{bcd}} \pm 0.01$ & $1.28^{\mathrm{defg}} \pm 0.05$ \\
\hline & 15 & $1.51^{\mathrm{bc}} \pm 0.01$ & $1.35^{\mathrm{ef}} \pm 0.01$ & $1.43^{\text {cdef }_{ \pm}} \pm 0.01$ & $1.33^{\text {bcdef }} \pm 0.01$ \\
\hline & 20 & $1.78^{\mathrm{a}} \pm 0.02$ & $1.71^{\mathrm{a}} \pm 0.04$ & $1.74^{\mathrm{a}} \pm 0.07$ & $1.76^{\mathrm{a}} \pm 0.06$ \\
\hline & 30 & $1.38^{\mathrm{cd}} \pm 0.04$ & $1.51^{\mathrm{bcd}} \pm 0.02$ & $1.57^{\mathrm{bc}} \pm 0.01$ & $1.44^{\mathrm{bcd}} \pm 0.04$ \\
\hline & 40 & $1.33^{\mathrm{de}} \pm 0.03$ & $1.44^{\text {bde }} \pm 0.09$ & $1.34^{\mathrm{ef}} \pm 0.02$ & $1.35^{\mathrm{bcdef}} \pm 0.07$ \\
\hline
\end{tabular}

Note: Different superscripts in the same row indicate statistically significant values $(P \leq 0.05)$. ${ }^{\text {ns }}$ mean values in the same row are not significantly different $(P>0.05)$; UBJ = Unpolished Black Job's tears; PBJ = Polished Black Job's tears; UWJ = Unpolished White Job's tears; PWJ = Polished White Job's tears.

\section{Effect of moisture content of pre-treated Job's tears grains on expansion ratio of puffed Job's tears grains}

The study of the moisture content of cooked Job's tears grains was implemented by drying the four forms of Job's tears grains using a tray dryer at $60^{\circ} \mathrm{C}$ for 6 hours. Random samples were taken every 30 minutes. The results suggested that the time periods affected the moisture content and expansion ratio of the four forms differently. It was found that Job's 
tears grains had differences in moisture content during the first $0-4$ hours and that these rapidly decreased (Figure 3). During 4.5-6.0 hours of drying, the moisture contents were slightly constant. After drying, the cooked Job's tears grains became pre-treated Job's tears grains that would be puffed using a microwave oven. Pre-treated Job's tears grains from each drying time were puffed at the maximum power of the microwave oven. All forms of pre-treated Job's tears grains could be expanded into puffed Job's tears grains (Figure 4). It was also found that all forms of pre-treated Job's tears grains could be puffed up to 1.45 expansion ratio. At this expansion ratio, the moisture content of pre-treated Job's tears grain was in the range of 8.00$10.60 \%$. These grains were dried at $60^{\circ} \mathrm{C}$ for about 5.5-6.0 hours (Figure 5).

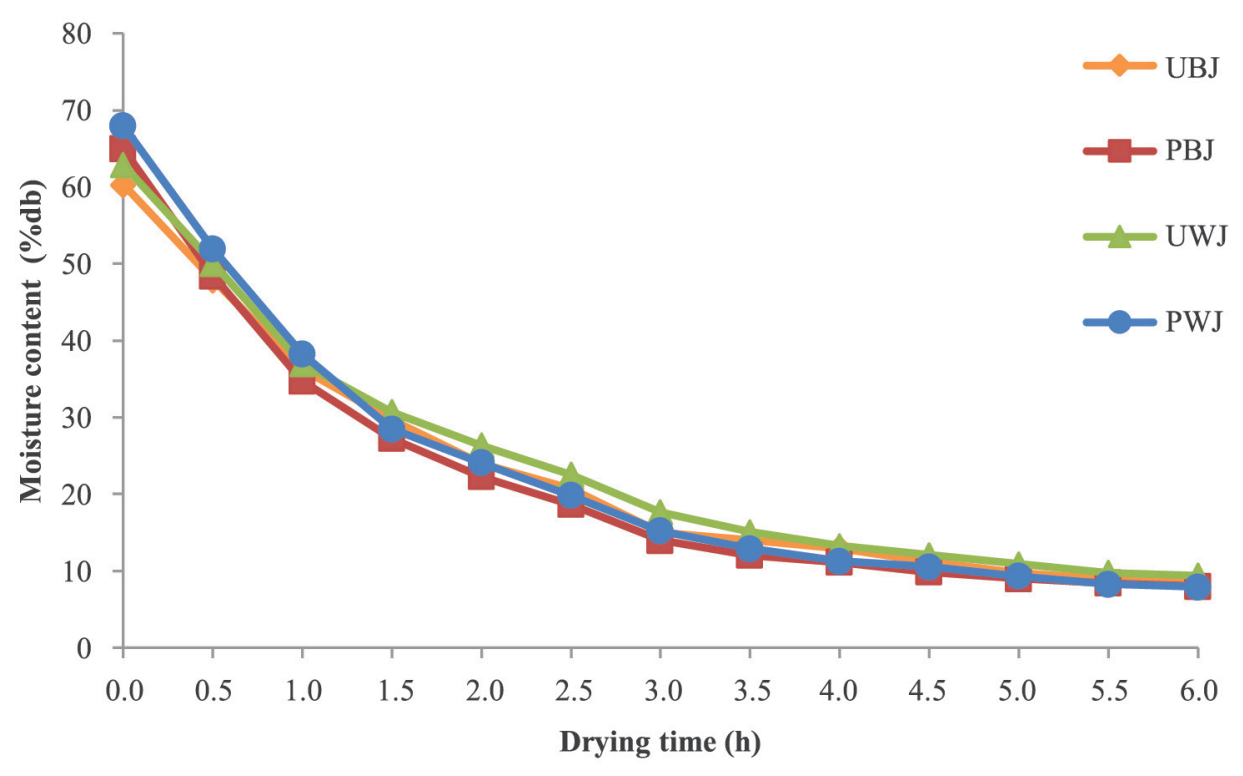

Figure 3. Moisture content for different drying times of each type of Job's tears grains (UBJ = Unpolished Black Job's tears; PBJ = Polished Black Job's tears; UWJ = Unpolished White Job's tears; PWJ = Polished White Job's tears). 


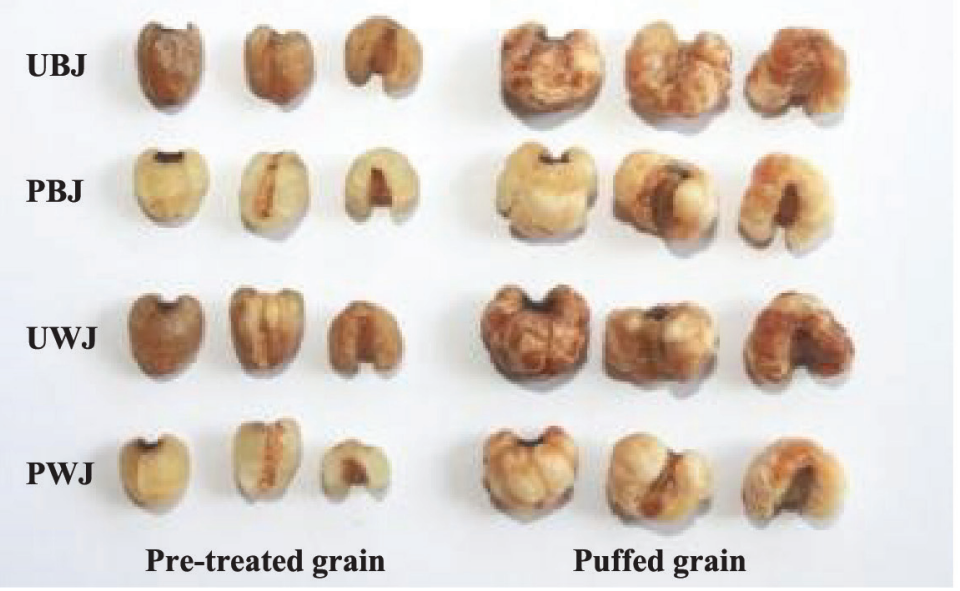

Figure 4. Puffed Job's tears grains using microwave oven (UBJ = Unpolished Black Job's tears; PBJ = Polished Black Job's tears; UWJ = Unpolished White Job's tears; PWJ = Polished White Job's tears).

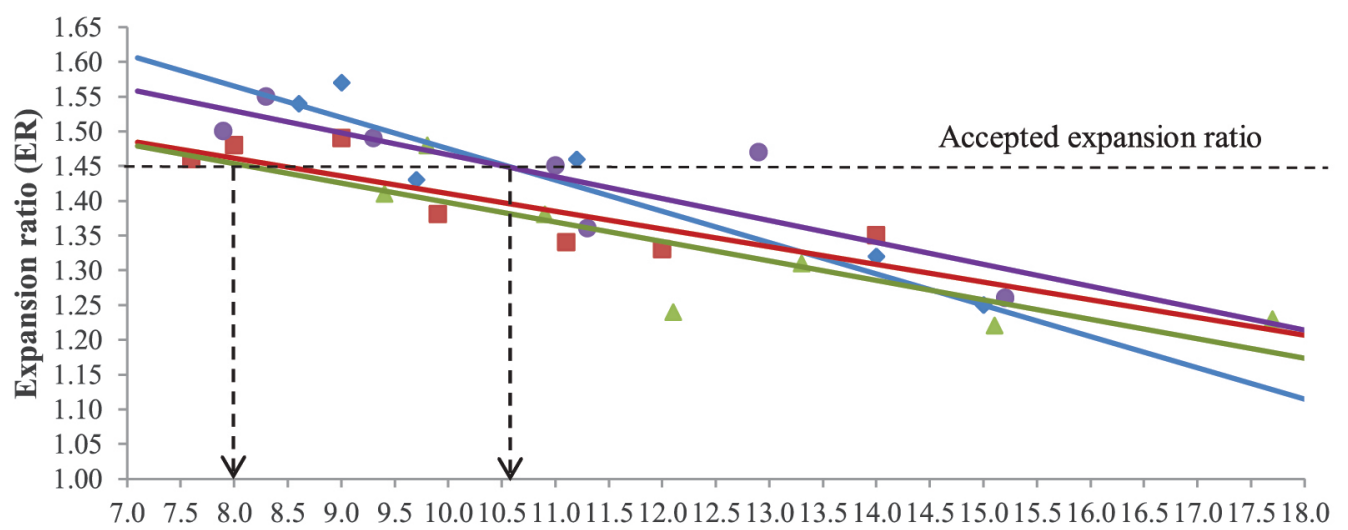

Equilibrium mositure content $(\% \mathrm{db})$

\begin{tabular}{|c|c|c|c|}
$\begin{array}{c}\text { ER of PWJ } \\
\text { ER of UBJ }\end{array}$ & $\begin{array}{l}\text { ER of PBJ } \\
\text { Trended line of PWJ }\end{array}$ & \multicolumn{1}{c}{$\begin{array}{c}\text { ER of UWJ } \\
\text { Trended line of PBJ }\end{array}$} \\
\cline { 1 - 2 } $\begin{array}{c}\mathrm{y}=-0.045 \mathrm{x}+1.925 \\
\mathrm{R}^{2}=0.870\end{array}$ & $\begin{array}{c}\mathrm{y}=-0.0255 \mathrm{x}+1.6647 \\
\mathrm{R}^{2}=0.6976\end{array}$ & $\begin{array}{c}\mathrm{y}=-0.0281 \mathrm{x}+1.6783 \\
\mathrm{R}^{2}=0.688\end{array}$ & $\begin{array}{c}\mathrm{y}=-0.0315 \mathrm{x}+1.7818 \\
\mathrm{R}^{2}=0.7016\end{array}$ \\
\hline
\end{tabular}

Figure 5. Moisture content and expansion ratio of each form of Job's tears grains (UBJ = Unpolished Black Job's tears; PBJ = Polished Black Job's tears; UWJ = Unpolished White Job's tears; PWJ = Polished White Job's. 


\section{DISCUSSION}

From the physical comparison study of four forms of Job's tears grains (UBJ, PBJ, UWJ, and PWJ), the two types of polished Job's tears grains (PBJ and PWJ) were similar in shape to the unpolished ones (UBJ and UWJ) but had white skin with a brown groove. That brown groove is part of a black layer which comes from the dead cells of the phloem after complete ripening and the covering of the embryo with endosperm. The part of the embryo attached to the black layer cannot be separated through attrition by a roller polishing machine. Thus, the widely consumed Job's tears grains still have the remaining embryos, which are mostly rich in important nutrients like vitamins, minerals, and essential fatty acids. In other words, the consumption of Job's tears can provide one with nutrients from their embryos. By contrast, other grains, such as white rice, do not retain embryos after the dehusking process. Polished Job's tears grains still have the potential for seed germination because of the retained embryos. Germination is the growth of the embryonic plant contained within a seed; it results in the formation of a seedling. The seed of a vascular plant is a small package produced in a fruit or cone after the union of the male and female sex cells. All fully developed seeds contain an embryo and, in most plant species, a store of food reserves wrapped in a seed coat. Some plants produce varying numbers of seeds that lack embryos. These are called empty seeds, and they never germinate (Pornchaloempong and Rattanapanone, 2014a).

When the basic chemical composition of each of the four forms of Job's tears grains was analyzed, the results showed that black Job's tears grains had higher amounts of protein, fat, and ash than white ones. Black Job's tears grains contained 14.22-14.29\% protein, 5.70$6.44 \%$ fat, and $2.12-2.29 \%$ ash, whereas white Job's tears grains contained $12.90 \%$ protein, $4.20-6.11 \%$ fat, and $0.33-0.69 \%$ ash (Table 1). When the basic chemical composition of unpolished black and white Job's tears grains was compared to that of polished ones, it was found that the unpolished grains (UBJ and UWJ) contained higher nutrient levels than the polished grains (PBJ and PWJ). Since the dehusking process could split the embryo apart, it caused the polished Job's tears grains to carry less fat, fiber, and ash than the unpolished grains. This explains the richness of the fat, fiber, and ash in the isolated embryo. The comparison of protein content revealed that unpolished Job's tears grains (UBJ and UWJ) and polished Job's tears grains (PBJ and PWJ) were not significantly different in protein content $(P>0.05)$. This protein accumulates while the grain is growing and turns into protein bodies, resulting in protein distribution across the grain and mostly in the endosperm (Naivikul, 2004). When the basic chemical compositions of black Job's tears (UBJ and PBJ) and white Job's tears (UWJ and PWJ) were compared, it was found that UBJ and PBJ contained higher amounts of protein, fat, crude fiber, and ash than UWJ and PWJ. This may be reflective of different cultivars, growing areas, and sample preparation processes resulting in different amounts of nutrients.

When comparing the chemical compositions of black and white Job's tears grains with the reports of Dechkunchorn (2008) and Chaisiricharoenkul et al. (2011), they also reported that the black Job's tears grains had higher protein, fat, fiber and ash contents than the white one. When comparing the chemical composition of Job's tears grains with those of whole grains for expanded products such as popcorn (7.71-14.60\% protein, 3.21-7.71\% fat, and $69.66-71.55 \%$ carbohydrate) (Ikram et al., 2010) and sticky rice (5.72\% protein, $0.49 \%$ fat, 
and $80.95 \%$ carbohydrate) (Department of Rice, 2014), it was evident that Job's tears grains and popcorn had similar amounts of protein, fat, and carbohydrate. That means that Job's tears grains had the potential to expand similarly to popcorn.

Comparisons to Dechkunchorn (2008) and Chaisiricharoenkul et al., (2011) reports of pure Job's tears starch, black Job's tears grains had amount of amylose content (29.22 and $17.01 \%$, respectively) but white Job's tears grains had the low amount of amylase content (11.55 and $10.34 \%$, respectively). As is evident, this study has revealed lower amounts of amylose than the studies that Dechkunchorn (2008) and Chaisiricharoenkul et al. (2011) conducted. Their studies analyzed amylose from the pure starch of Job's tears grains, but this study experimented on Job's tears flour, which included other elements, such as protein and fat. The different quantities of amylose may result from different cultivars, growing areas, and sample preparation processes, such as polishing and not polishing.

Total dietary fiber (TDF) from this study was showed that black Job's tears grains and unpolished Job's tears grains had higher TDF than white Job's tears grains and polished Job's tears grains. TDF constitutes the cell walls of plants (fruits, vegetables, and cereal grains). It is not digestible in the gastrointestinal tract; therefore, it provides no energy. Unpolished whole cereal grains are an important source of insoluble dietary fiber, which swells like a sponge in water without viscosity. The fiber increases the water volume in the stomach, contributing to satiety. This fiber cannot be digested by intestinal bacteria, and it increases stool texture. Thus, it reduces constipation and the risk of colon cancer. Moreover, Job's tears grains are also a food supply with high fiber content: over $3 \mathrm{~g}$ of TDF per $100 \mathrm{~g}$ of food (Pornchaloempong and Rattanapanone, 2014b).

Based on coixenolide content, Yang et al. (2004) and Chaisiricharoenkul et al., (2011) found that different levels of coixenolide $(0.02 \mu \mathrm{g} / \mathrm{g}$ and $532 \mu \mathrm{g} / \mathrm{g}$, respectively) may result from different cultivars, growing areas, and sample preparation processes yielding different amounts of nutrients. When the chemical compositions of polished and unpolished black Job's tears grains and white Job's tears grains were analyzed and compared, it was found that unpolished Job's tears grains (UBJ and UWJ) had greater levels of nutrients than polished ones (PBJ and PWJ), showing a richness of vitamins and minerals in the embryos of Job's tears grains. The isolated embryos of Job's tears grains should also be rich in essential fatty acids and fat-soluble antioxidants according to the report of Pornkitprasarn and Naivikul (1987). The grains should experience a loss in vitamins and minerals through attrition.

When comparing the water uptake of black Job's tears grains with that of white Job's tears grains, it was found that black Job's tears grains could absorb water to a greater extent than white Job's tears grains. That probably had to do with the interior and exterior structural strength of white Job's tears grains, making their starch granules absorb water slowly and swell to a lesser extent (Cheeppensuk, 2005). Meanwhile, the solid loss from soaking had apparently increased during the first 0-2 hours and then been constant in the soaking periods, during which UBJ, PBJ and UWJ had shown similarity and no statistical difference $(P>0.05)$. The solid loss from soaking the black Job's tears grains was similar to that from soaking the white Job's tears grains. When comparing unpolished Job's tears grains (UBJ and UWJ) with polished Job's tears grains (PBJ and PWJ), a greater amount of unpolished Job's tears grains (UBJ and UWJ) was found than that of polished Job's tears grains (PBJ and PWJ), probably due to higher amylose, protein, and fat content. The amylose and protein could be 
removed from the structure of the starch granules during the swelling (Simi and Abraham, 2008) because the Job's tears grains that had experienced a longer soaking time could absorb more water than ones that had experienced a shorter soaking time. Besides, it was found that white Job's tears grains became smelly and had sticky mucus after soaking for 16 hours, whereas black Job's tears grains became smelly after soaking for 24 hours. According to the study on the duration of soaking in water at room temperature, the water absorption and the moisture content of the PBJ, UWJ and PWJ after 10 hours and the UBJ after 8 hours of soaking were stable and the soaking time had had no effect on solid loss during soaking. Ten hours of soaking at room temperature were selected for the four forms of Job's tears grains.

After cooking at autoclave (15 psi for 20 minutes), Job's tears grains provide the highest expansion ratio since the crystal structures of starch were destroyed and then Job's tears grains were easy to expand. This result is in agreement with Chaisiricharoenkul et al. (2011) report, which indicated that steaming in an autoclave destroyed the crystal structure of Job's tears grains. When starch not processed by steaming in an autoclave was compared to the crystal structure of Job's tears, the result was relevant to the research paper of Chang et al. (1998). The paper in question described a study on the effect of thermal processing techniques on the physical and chemical properties of Job's tears grains. It revealed that the crystal structure of husked Job's tears grains was also destroyed after processing by steaming in an autoclave at $121^{\circ} \mathrm{C}$ for 30 minutes. Thus, steaming in an autoclave at 15 psi for 20 minutes was selected as a result that was linked to the highest expansion ratio for the four forms of Job's tears grains. Apart from cooking conditions, the moisture content before baking is among the factors that affect expansion. Therefore, the proper moisture content of Job's tears grains that contributes to the optimal puffing of each form of Job's tears grains and is most practically convenient must be implemented for further studies.

In this research, it was found that moisture content of pre-treated Job's tears grains had effect on expansion ratio after microwave puffing. Corresponding to Sabri's report (2004) that the effects of moisture content on the popping quality of popcorn were equilibrated to seven moisture levels ranging from $8.00-20.00 \%$. The popcorn was popped by a microwave oven, a hot-air popper, and a cooking pan with and without oil and salt. Fan et al. (1999) recorded that initial moisture content caused an increase in the expansion ratio, as was explained earlier. This, in turn, reduced the hardness of the snack up to a certain limit. Moisture content, when increased beyond a certain level, adversely affected expansion, as was explained earlier. Therefore, lower expansion resulted in the increased hardness of the snack. So, from this $60^{\circ} \mathrm{C}$ drying temperature study, the suitable moisture content of all forms of pre-treated Job's tears grains should be $8.00-10.60 \%$.

\section{CONCLUSIONS}

The raw materials of Job's tears in this study included four forms; unpolished black Job's tears (UBJ), polished black Job's tears (PBJ), unpolished white Job's tears (UWJ), and polished white Job's tears (PWJ). Each form of Job's tears grains was pre-treated in three steps (which consisted of soaking, cooking, and drying) before microwave puffing. Moreover, each process was studied to determine the optimal conditions. By soaking Job's 
tears grains in water for 24 hours at room temperature, it was found that the suitable soaking time was 10 hours. This was the minimal soaking time that facilitated constant water uptake. Cooking using the autoclave at 5 psi for 20 minutes was suitable for a good expansion ratio of microwavable puffed grains. The grains were dried with the tray dryer at $60^{\circ} \mathrm{C}$ for about 5.56.0 hours until the achievement of an 8.00-10.60\% moisture content suitable for pre-treated Job's tears grains. Microwave puffing at this moisture content revealed the puffed Job's tears grains to have a high expansion ratio. Optimal pre-treatment from this study could be applied to all forms of studied Job's tears.

\section{ACKNOWLEDGEMENTS}

Special thanks to the Thailand Research Fund (TRF) and the Maelek Food Product Limited Partnership for funding this research.

\section{REFERENCES}

AOAC (Association of Official Analytical Chemists). 2005. Official methods of analysis of the association of analytical chemists international. $18^{\text {th }}$ ed. The United State of America.

Bunthawong, O., Pikasem, S., and Intanun, W. 2012. Effect of processing methods on products quality of puffed Job's tears snack. Hands-on Research and Development, Rajamangala University of Technology Lanna (RMUTL) report, Chiang Mai, Thailand.

Chaisiricharoenkul, J., Tongta, S., and Intarapichet, K.-O. 2011. Structure and chemical and physicochemical properties of Job's tear (Coix lacryma-jobi L.) kernels and flours. Suranaree Journal Science Technology. 18(2): 109-122.

Chang, Y.K., Bustos, F.M., and Lara, H. 1998. Effect of some extrusion variables on rheological properties and physicochemical changes of cornmeal extruded by twin screw extruder. Brazilian Journal of Chemical Engineering. 15(4). https://doi.org/10.1590/S010466321998000400006

Cheeppensuk, R. 2005. Job's Tears: Potential and innovation of food products processing. The faculty of science and technology, Phranakhon Rajabhat University, Bangkok, Thailand.

Dechkunchorn, M. 2008. Characterization of adlay (Coix lachryma-jobi L.) starch and flour and the effect of coixin protein on physiochemical property of composite adlay flour. Master Thesis, Kasetsart University, Chalermphrakiat Sakon Nakhon Province Campus, Thailand.

Department of Rice: Chemical composition and nutrition value of sticky rice online [Internet]. [cited 2014 Oct 2]. Available from http://riceproduct.org/index

Fan, S., Hsieh, F., and Huff, H.E. 1999. Puffing of wheat cakes using a rice cake machine. Applied Engineering in Agriculture. 15: 677-684. https://doi.org/10.1111/j.1365-2621.1989. tb05980.x

Finglasa, P.M., and Faulksa, R.M. 1994. The HPLC analysis of thiamin and riboflavin in potatoes. Food Chemistry. 15: 37-44. https://doi.org/10.1016/0308-8146(84)90037-2 
Ikram U., Mohammed, A., and Arifa, F. 2010. Chemical and nutritional properties of some maize (Zea mays L.) varieties grown in NWFP, Pakistan. Pakistan Journal of Nutrition. 9(11): 1113-1117. https://doi.org/10.3923/pjn.2010.1113.1117

Jannoey, P., Niamsup, H., Lumyong, S., Suzuki, T., Katayama, T., and Chairote, G. 2010. Comparison of gamma-amino butyric acid production in Thai rice grains. World Journal of Microbiology and Biotechnology. 26(2): 257-263. https://doi.org/10.1007/ s11274-009-0168-2

Jomduang, S. 1994. Modification and improvement of "Khao Kriap Waue" (A traditional Thai glutinous rice-based snack food). Doctoral desertatia, University Pertanian, Malaysia.

Juliano, B.O. 1971. A simplified assay for milled rice amylose. Cereal Science Today. 16: 334-338.

Naivikul, O. 2004. Rice: science and technology. Kasetsart University, Bangkok, Thailand.

Nath, A., and Chattopadhyay, P.K. 2008. Effect of process parameters and soy flour concentration on quality attributes and microstructural change in ready-to-eat potatosoy snack using high-temperature short time air puffing. LWT-Food Science and Technology. 41: 707-715. https://doi.org/10.1016/j.lwt.2007.05.001

Neher, B., Bhuiyan, M.R., Kabir, H., Qadir, R., Gafur, A., and Ahmed, F. 2014. Study of mechanical and physical properties of palm fiber reinforced acrylonitrile butadiene styrene composite. Materials Sciences and Applications. 5: 39-45. https://doi. org/10.4236/msa.2014.51006

Pornkitprasarn, T., and Naivikul, O. 1987. The comparison of chemical and physical properties of Job's tears flour and starch. Kasetsart Journal (Social Sciences). 21(4): 371-377.

Pornchaloempong, P., and Rattanapanon, N. 2014a. Germination [Internet]. [cited 2014 Oct 22]. Available from: http://en.wikipedia.org/wiki/Germination\#cite_note-1

Pornchaloempong, P., and Rattanapanone, N. 2014b. Dietary fiber [Internet]. [cited 2014 Apr 6]. Available from: http://www.foodnetworksolution.com/wiki/word/1102/dietaryfiber

Sabri, G. 2004. Effects of moisture content and popping method on popping characteristics of popcorn. Journal of Food Engineering. 65: 357-362. https://doi.org/10.1016/j. jfoodeng.2004.01.034

Simi, C.K., and Abraham, T.E. 2008. Physicochemical rheological and thermal properties of Njavara rice (Oryza sativa) starch. Journal of Agricultural and Food Chemistry. 56: 12015-12113. https://doi.org/10.1021/jf802572r

Tanimura, A. 1961. Studies on anti-tumor component in the seeds of Coix lachrymal-jobi L. var. Ma-yuen (ROMAN.) Stapf. II. The structure of coixenolide. Chemical and Pharmaphysical Bulletin. 9(1): 47-53. https://doi.org/10.1248/cpb.9.47

Ukita, T., and Tanimura, A. 1961. Browning reaction products produced by the reaction between sugars and amino acids. VII. Decomposition of lipid hydroperoxide by the browning products. Nippon Shokuhin Kogyo Gakkaishi. 15: 187-191.

Yang, J.-H., Tseng, Y.-H., Chang, H.-L., Lee, Y.-L., and Mau, J.-L. 2004. Storage stability of monascal adlay. Food Chemistry. 90: 303-309. https://doi.org/10.1016/j. foodchem.2004.03.053 